\title{
Infertility history and age do not change embryonic aneuploi- dies rates in IVF cycles: 2084 analyzed human blastocysts by Array-CGH
}

\section{A história de infertilidade e a idade não afetam os níveis de aneuploidias em ciclos FIV: 2084 blastocistos humanos analisados por CGH-array.}

\author{
José Roberto Alegretti ${ }^{1,2}$, Ana Luiza Sgarbi Rossi ${ }^{1}$, Marcia Riboldi ${ }^{1}$, Bruna Camilo de Barros ${ }^{1}$, Paulo Cesar Serafini ${ }^{1,3}$, \\ Eduardo Leme Alves da Motta ${ }^{1,2}$ \\ ${ }^{1}$ Huntington Medicina Reprodutiva, São Paulo, Brazil. \\ Accredited Redlara center \\ 2 Universidade Federal de São Paulo (UNIFESP), Disciplina de Ginecologia, São Paulo, Brazil. \\ ${ }^{3}$ Universidade de São Paulo (USP), Departamento de Ginecologia Setor de Reprodução Humana, São Paulo, Brazil.
}

Institution: Huntington Medicina Reprodutiva

Support : none

Congresses where the study was presented : none

\begin{abstract}
Objetive: To evaluate rate blastocyst aneuploidy after Array-CGH in different age groups with different infertility history in couples submitted to IVF.

Methods: 598 cycles were evaluated and 2084 blastocysts between 11/2010- 01/2013. Embryo biopsy was performed on blastocyst and sample was performed to Array-CGH analysis. Patients were divided in 4 groups according to maternal age: A) $\leq 34$ years old(yo); B)35-37yo; C)38-40yo and D) $\geq 41$ yo. The couples infertility history were classified in 6 groups: 1 ) +1 IVF failure (IVFF) and +1 abortion $(A B)$; 2) 1 IVFF without $P M$; 3) $1 A B$ without IVFF; 4) +2 IVF without $P M ; 5)+2 A B$ without IVFF and 6) no failures. The aneuploidies were divided in 4 groups: I) Monosomy; II)Trisomy; III)Multiple and IV)Complex. Were also verified the rate of deletions, duplications and DNA degradation.
\end{abstract}

Results: Analysis of aneuploidy rate by age groups showed statistical differences in group 1 [AXD ( $p=$ $0.041)$ and $B \times C(p=0.005)]$, Group $3[A \times B(p=$ $0.05), \operatorname{AxC}(p=0.05)$ and $\operatorname{AXD}(p=0.02)]$, Group 4 [AXD $(p=0.011), B \times D(p=0.002)$ and CXD $(p=0.03)$ ], Group 5 [AXC $(p=0.013), A X D(p=0.001)$ and CXD $(p=0.018)]$ and Group 6 [AXC $(p=0.001), A X D$ $(p=0.001), B \times C(p=0.013)$ and $B \times D(p=0.001)]$. Group 2 did not differ between age groups. However, the comparative analysis between the types of aneuploidy found in all age groups and infertility factors showed no statistically significant differences

Conclusions: Our study suggests that the presence of embryonic chromosomal abnormalities is not related with the infertility history. Similar maternal age groups with different backgrounds showed the same incidence of the chromosomal abnormalities.

Key-Words: Comparative Genomic Hybridization, Maternal age, Preimplantation diagnosis, Aneuploidy
Objetivo: Avaliar taxa de aneuploidias em blastocistos após CGH-array em diferentes grupos etários com história diferente de infertilidade em casais submetidos à FIV. Métodos: 598 ciclos foram avaliados e 2084 blastocistos entre 11/2010-01/2013. Biópsia foi realizada em blastocistos e da amostra foi realizado o $\mathrm{CGH}$. Os pacientes foram divididos em quatro grupos segundo a idade materna: A) $\leq 34$ anos, B) $35-37$; C) $38-40$ e D) $\geq 41$. Segundo a história de infertilidade resultaram seis grupos: 1) +1 FIV (IVFF) e +1 (AB); 2) 1 IVFF sem PM; 3) $1 A B$ sem IVFF; 4) +2 FIV sem PM; 5) +2 AB sem IVFF e 6 ) sem falhas. As aneuploidias foram divididos em quatro grupos: I) Monossomia; II) Trissomia; III) Múltipla e IV) Complexa. Também foram verificados a taxa de deleções, duplicações e degradação do DNA. Resultados:A análise da taxa de aneuploidia por grupos etários apresentaram diferença estatística no grupo 1 [AXD $(p=0,041)$ e $\operatorname{BxC}(p=0,005)]$, Grupo $3[\operatorname{AxB}(p=0,05), A \times C(p=$ $0,05)$ e $\operatorname{AXD}(p=0,02)]$, Grupo 4 [AXD $(p=0,011)$, $\operatorname{BxD}(p=0,002)$ e $\operatorname{CXD}(p=0,03)]$, Grupo $5[A \times C(p=$ $0,013), \operatorname{AXD}(p=0,001)$ e CXD $(p=0,018)]$ e Grupo 6 $[\operatorname{AxC}(p=0,001), \operatorname{AXD}(p=0,001), \operatorname{BxC}(p=0,013)$ e $\operatorname{BxD}(p=0,001)]$. Grupo 2 não diferiu entre os grupos etários. No entanto, a análise comparativa entre os tipos de aneuploidia encontrados em todos os grupos de idade e fatores de infertilidade não apresentaram diferenças estatisticamente significativas. Conclusões: Sugerese que a presença de anormalidades cromossômicas embrionárias não está relacionada com a história de infertilidade. Grupos etários maternos similares com diferentes históricos mostraram a mesma incidência de anormalidades cromossômicas.

\section{INTRODUCTION}

In the reproductive life, the more important factor that affects the women is the age. The average age in which women become pregnant depends on several factor such as region, socioeconomic status, education level, career 
planning. However, over the last decades, a trend of child bearing at older ages has been observed all over the world, especially in the Western countries (Baird, Collins et al. 2005). Women tend to focus on their careers rather than becoming a mother.

Infertility factor affect approximately $15 \%$ of couples (de Kretser 1997), and genetic abnormalities are responsible for high part of this problem. Chromosomal abnormality increases with advanced maternal age, leading to a decrease in embryo implantation rate, an enhanced risk of miscarriage, or an enhanced risk of aneuploid offspring (Delhanty 2005).

However, despite the advances on assisted reproduction techniques (ART), for women above 35 years of age, the longer they wait to child bearing, the higher are the chances of experiencing delays and disappointment due to decreased fertility (Menken, Trussell et al. 1986, Carolan and Frankowska 2010, Salem Yaniv, Levy et al. 2011, Wang, Tanbo et al. 2011). Reasons for such adverse effect of advanced maternal age (AMA) on fertility includes the limited number of female germ cells, the decrease on the number of oocytes from birth to menopause, the quality of existing oocytes diminishes with age (Baird, Collins et al. 2005, Luke and Brown 2007).

Among the age related problems known to adversely affect oocyte quality, the higher risks of genetic abnormalities generates great concern; an exponential increase on likelihood of delivering an affected child is found according to AMA (Rius, Daina et al. 2011, Wang, Tanbo et al. 2011). Previous studies indicate that genetic abnormalities are involved in 50-80\% of first-trimester miscarriages (Guerneri, Bettio et al. 1987), (Schaeffer, Chung et al. 2004), 20-30\% of neonatal deaths (Hudome, Kirby et al. 1994), (Cunniff, Carmack et al. 1995), and $30-50 \%$ of postnatal deaths (Hoekelman and Pless 1988).

The introduction of comparative genomic hybridization (Array-CGH) enhanced the ability of the laboratory evaluated the embryo development. Firstly it enables an analysis of the entire chromosome complement and evaluate losses and gains (Alfarawati, 2011). Further, the analysis made possible in a blastocyst stage, which offers a more cells for analysis and the biopsy minimizes the impact on embryonic development in comparison to the cleaved embryo (Treff, 2011).

Indications suggested for genetic analyses are advanced maternal age (AMA; usually defined as maternal age over 37 or 38 years), repeated implantation failure (RIF; usually defined as three or more failed embryo transfer procedures involving high-quality embryos) (Gianaroli, Magli et al. 1999), repeated miscarriage (RM) in patients with normal karyotypes (usually at least three previous miscarriages) (Pellicer, Rubio et al. 1999) and severe male factor (SMF) infertility (usually defined as abnormal semen parameters) (Silber, Escudero et al. 2003, Goossens, Harton et al. 2009, Harper, Coonen et al. 2010).

Actuality, the major number of the couples seeks the reproductive clinical. The use of controlled ovarian stimulation in assisted reproductive treatment (ART) cycles generally results in the production of multiple mature oocytes. Fertilization rates are usually high and consequently it is typical for several embryos to be produced each treatment cycle. In order to maximize the probability of obtaining a pregnancy, most in vitro fertilization (IVF) cycles involve the transfer of more than one embryo. The diagnosis of genetic defects in PGD embryos would allow those unaffected to be identified and transferred to the uterus, prioritizing the haploid embryo transfer.

The objective of this study was to evaluate the relation between maternal age and infertility history with different types of chromosomal abnormalities in patients submitted a IVF cycles with ovarian stimulation.

\section{MATERIAL AND METHODS}

\section{Patients}

Between November/ 2010 and January 2013/ 2012, 598 IVF/ICSI cycles with blastocyst biopsy were analyzed retrospectively. Cycles were divided in four groups according to women's age: Group A: $\leq 34$ years / 104 cycles; Group B: 35 - 37 years old / 124 cycles; Group C: $38-40$ years old / 185 cycles; Group D: $\geq 40$ years old / 185 cycles.

The cycles also were divided into 6 groups according to the infertility history:

Group 1 - Presence of 1 or more IVF failure and 1 or more abortion

Group 2 - Presence of 1 IVF failure only

Group 3 - Presence of 1 abortion only

Group 4 - Presence of 2 or more IVF failures without abortion Group 5 - Presence of 2 or more abortion without IVF failure Group 6 - No failures

A total of 2084 blastocysts biopsied with 5 days of development were involved in the study.

\section{2) In Vitro Fertilization Protocol}

The ovarian stimulation protocol ( $\mathrm{GnRH}$ agonist or antagonist) was determined according with the patient characteristic. After ovarian pick-up, all oocytes were cultured in incubation medium supplemented with $5 \%$ human albumin (G-Plus IVF, Vitrolife) until the moment of fertilization. Fertilization was conducted by intracytoplasmic sperm injection (ICSI) or conventional, according to a final concentration of motile sperm obtained. Embryos normally fertilized were cultured until day 3 in culture medium G-1-Plus Series 5 (Vitrolife) supplemented with $5 \%$ human albumin. In all embryos which had a minimum of 4 cells in day 3 assisted hatching by laser was performed. This procedure created a hole on the zona pellucida to promote the trophoblastic herniation. All embryos with herniation on Day 5 were biopsied in the morning of Day 5 . The trophoblastic cells were transferred to eppendorf microtubes and sent to analysis by array-CGH.

\section{3) Comparative Genome Hybridization microarray (aCGH)}

Each sample biopsied (trophectoderm cells) was washed in sterile phosphate-buffered saline and Transferred to the 2UL Microcentrifuge tube in lysis of the solution. To generate the $\sim 1 \mathrm{mg}$ of DNA required for aCGH analysis, the biopsied cells were lysed and the whole genome amplified using degenerate oligonucleotide-primed polymerase chain reaction. Amplified DNA was labeled with a green fluorescent molecule (Spectrum Green-dCTP, G \& E Healthcare). Similarly, DNA from a chromosomally individual standard was labeled with red fluorescence (Spectrum Red-dCTP, E G \& Healthcare). The green (embryo) and red (normal reference) DNAs were mixed together and hybridized Simultaneously on BAC - array platform Able to cover all the 24 chromosomes. Scanned images were Analyzed and quantified, and whole chromosomal copy number ratios were Reported using the array-analysis software.

\section{4) Characterization of aneuploidy and chromosomal} errors

The results obtained by the analysis of aCGH were classified 
into 6 groups according to the chromosomal errors: I - Simple monosomy

II - Simple trisomy

III - Multiple (two or three chromosomes Involved)

IV - Complex (four or more chromosomes Involved)

$\mathrm{V}$ - Deletion

VI - Duplication

We also verified too the incidence of DNA degradation

\section{Statistical Analysis}

Kruskal-Wallis were used to the non-parametrical analysis and Dunn tests were used to multiple nonparametrical comparison.

\section{RESULTS}

The overall study included 2084 embryos/blastocysts biopsied from 598 cycles that underwent Array-CGH analysis. Array-CGH yielded a result in 2004/2084 analyzed embryos $(96,2 \%)$ with the rest showing no analyzable results either due to degraded DNA or amplification failure caused by anucleated biopsied cells or cells lost during the transfer to the tube.

According the history of infertility the group were divided and were obtained: Group 1)102 cycles; Group 2)76 cycles; Group 3)62 cycles; Group 4)95 cycles; Group 5)59 cycles; Group 6)204 cycles. A total of 2084 blastocysts, the percentages of euploid $(26.5 \%)$ and aneuploid embryos (73.5\%) are presented in Table 1. The analyses of cycles related according to maternal age were obtained: Group A)104 cycles; Group B)124 cycles; Group C)185 cycles; Group D)185 cycles. (Table 2).

Table 1. Number the cycles for group, number of the blastocysts analyses and embryonic euploidy rate, after Array-CGH analyses. (IVFF = In Vitro Fertilization Failure; $A B=$ abortion)

\begin{tabular}{lccc}
\hline Grous & $\begin{array}{c}\mathbf{N}^{\circ} \\
\text { cycles }\end{array}$ & $\begin{array}{c}\mathbf{N}^{\circ} \\
\text { blastocysts } \\
\text { analyses }\end{array}$ & $\begin{array}{c}\mathbf{N}^{\circ} \text { Aneuploid } \\
/ \%\end{array}$ \\
\hline $\begin{array}{l}\text { More than } 1 \\
\text { IVFF and } 1 \mathrm{AB}\end{array}$ & 102 & 360 & $270(75.0 \%)$ \\
\hline $\begin{array}{l}1 \text { IVFF only } \\
1 \text { AB only }\end{array}$ & 72 & 696 & $483(69.3 \%)$ \\
\hline $\begin{array}{l}\text { More than } 2 \\
\text { IVFF }\end{array}$ & 95 & 214 & $160(74.7 \%)$ \\
\hline $\begin{array}{l}\text { More than } \\
2 \text { AB }\end{array}$ & 59 & 348 & $253(72.7 \%)$ \\
\hline No failures & 204 & 207 & $162(78.2 \%)$ \\
\hline Total & 598 & 2084 & \\
\hline
\end{tabular}

The blastocysts analyses revealed significant differences in the aneuploid rates between infertility history groups 1, 3, 4,5 and 6 according different maternal age groups. No significance differences were found in group 2 (Table 3 ).

Significance differences were observed when the full analysis for the different age groups and types of proposed chromosomal errors, these results are displayed in Table $4 a$ and $4 b$. The analyses of the different types of chromosomal errors revealed not significant differences between all infertility history groups and all maternal age groups. Only significance differences was observed on deletion rate upper than 40 years old (Table 5 ).
Table 2. Number of the cycles according to infertility history and maternal age groups. (IVFF = In Vitro Fertilization Failure; $\mathrm{AB}=$ abortion

\begin{tabular}{llllllll}
\hline Group & $\begin{array}{c}\text { More } \\
\text { than 1 } \\
\text { IVFF } \\
\text { and 1 } \\
\text { AB }\end{array}$ & $\begin{array}{c}\text { IVFF } \\
\text { IVnly }\end{array}$ & $\begin{array}{c}\text { 1 AB } \\
\text { only }\end{array}$ & $\begin{array}{c}\text { More } \\
\text { than } \\
\mathbf{2} \\
\text { IVFF }\end{array}$ & $\begin{array}{c}\text { More } \\
\text { than } \\
\text { 2 AB }\end{array}$ & $\begin{array}{c}\text { No } \\
\text { failures }\end{array}$ \\
\hline $\begin{array}{l}\leq 34 \\
\text { years } \\
\text { old }\end{array}$ & 11 & 8 & 9 & 16 & 11 & 49 \\
\hline $\begin{array}{l}35 \text { to } 37 \\
\text { years } \\
\text { old }\end{array}$ & 26 & 13 & 13 & 20 & 14 & 38 \\
\hline $\begin{array}{l}38 \text { to } 40 \\
\text { years } \\
\text { old }\end{array}$ & 26 & 28 & 20 & 38 & 15 & 58 \\
\hline $\begin{array}{l}\geq 40 \\
\text { years } \\
\text { old }\end{array}$ & 39 & 27 & 20 & 21 & 19 & 59 \\
\hline \begin{tabular}{l} 
Total \\
\hline
\end{tabular} & 102 & 76 & 62 & 95 & 59 & 204 \\
\hline
\end{tabular}

Table 3. Analyses of significance differences $(p<0,05)$ between maternal age groups ( $A=\leq 34$ years old; $B=35$ to 37 years old; $C=38$ to 40 years old and $D=\geq 40$ years old) and prior infertility history ((IVFF $=$ In Vitro Fertilization Failure; $A B=$ abortion)

\begin{tabular}{ccccccc}
\hline Group & $\begin{array}{c}\text { More } \\
\text { than } \\
\mathbf{1} \\
\text { IVFF } \\
\text { and 1 } \\
\text { AB }\end{array}$ & $\begin{array}{c}\mathbf{1} \\
\text { IVFF } \\
\text { only }\end{array}$ & $\begin{array}{c}\mathbf{1} \text { AB } \\
\text { only }\end{array}$ & $\begin{array}{c}\text { More } \\
\text { than } \\
\mathbf{2} \\
\text { IVFF }\end{array}$ & $\begin{array}{c}\text { More } \\
\text { than 2 } \\
\mathbf{A B}\end{array}$ & $\begin{array}{c}\text { No } \\
\text { failures }\end{array}$ \\
\hline $\mathrm{A} \times \mathrm{B}$ & 0.960 & 0.991 & 0.050 & 0.675 & 0.169 & 0.575 \\
\hline $\mathrm{A} \times \mathrm{C}$ & 0.550 & 0.119 & 0.030 & 0.394 & 0.013 & 0.001 \\
\hline $\mathrm{A} \times \mathrm{D}$ & 0.041 & 0.108 & 0.002 & 0.011 & $<0.001$ & $<0.001$ \\
\hline $\mathrm{B} \times \mathrm{C}$ & 0.960 & 0.991 & 0.050 & 0.675 & 0.169 & 0.575 \\
\hline $\mathrm{B} \times \mathrm{D}$ & 0.005 & 0.053 & 0.267 & 0.002 & 0.018 & $<0.001$ \\
\hline $\mathrm{C} \times \mathrm{D}$ & 0.057 & 0.934 & 0.236 & 0.030 & 0.239 & 0.052 \\
\hline Total & 102 & 76 & 62 & 95 & 59 & 204 \\
\hline & & & & & & \\
\hline
\end{tabular}

\section{DISCUSSION}

The incidence of chromosomal abnormalities found in humans varies enormously, depending on the technique of genetic analysis used (e.g., PCR, FISH, CGH), and the developmental "point" being examined (e.g., newborns, stillbirths, fetal abortions, early missed abortion, embryos, oocytes). While PCR is directed to a determined gene, FISH assess only a limited number of chromosomes. Therefore, the information obtained may not always be representative of their real chromosomal status. With the introduction of the $\mathrm{CGH}$ it is possible now to study, prior embryo transfer, the full karyotype of cleavage-stage and blastocyst stage embryos (Rius, Daina et al. 2011).

Furthermore, controversial results have been obtained using the FISH for the PGS; while some studies verify no effect at all (Twisk, Mastenbroek et al. 2008, Schoolcraft, Katz-Jaffe et al. 2009), other observe even a decrease on pregnancy rates (Mastenbroek, Scriven et al. 2008). However, according to the ESHRE PGD Consortium Steering Committee, some of those results may be due to differences on embryo stage of development at the moment of biopsy (polar body, cleavage stage and 
Table 4a. Analyses of significance differences $(p<0,05)$ between maternal age groups $(A=\leq 34$ years old; $B=35$ to 37 years old; $C=38$ to 40 years old and $D=\geq 40$ years old) and prior infertility history (groups 1,2 and 3 ) according to proposed chromosomal errors. (IVFF = In Vitro Fertilization Failure; $A B=$ abortion)

\begin{tabular}{|c|c|c|c|c|c|c|c|}
\hline & Group & $<=34(\%)$ & $35-37(\%)$ & $38-40(\%)$ & $>40(\%)$ & $\boldsymbol{P}$ & Total (\%) \\
\hline \multirow{8}{*}{$\begin{array}{l}\text { More than } 1 \\
\text { IVFF and more } \\
\text { than } 1 \mathrm{AB}\end{array}$} & aneuploid & 64.2 & 63.0 & 73.0 & 85.1 & 0.013 & 74.1 \\
\hline & Monosomy & 16.7 & 32.4 & 22.6 & 14.9 & 0.116 & 21.5 \\
\hline & Trisomy & 16.7 & 12.5 & 14.3 & 7.6 & 0.224 & 11.5 \\
\hline & multiple & 35.6 & 17.9 & 32.4 & 40.0 & 0.053 & 31.9 \\
\hline & complex & 9.2 & 22.5 & 19.8 & 35.2 & 0.276 & 25.4 \\
\hline & duplication & 0.00 & 4.8 & 4.6 & 0.6 & 0.171 & 2.6 \\
\hline & deletion & 13.6 & 1.0 & 3.2 & 0.00 & $<0.001$ & 2.5 \\
\hline & DNA degradation & 1.1 & 3.6 & 7.2 & 1.9 & 0.186 & 3.6 \\
\hline \multirow{8}{*}{1 IVFF only } & aneuploid & 68.1 & 63.0 & 81.7 & 80.7 & 0.081 & 76.7 \\
\hline & Monosomy & 18.8 & 27.8 & 19.2 & 13.0 & 0.399 & 18.4 \\
\hline & Trisomy & 18.8 & 15.4 & 15.6 & 6.5 & 0.274 & 12.7 \\
\hline & multiple & 46.9 & 32.3 & 30.4 & 40.4 & 0.509 & 36.0 \\
\hline & complex & 15.6 & 24.5 & 23.2 & 31.8 & 0.791 & 25.6 \\
\hline & duplication & 0.0 & 0.0 & 4.3 & 3.7 & 0.230 & 2.9 \\
\hline & deletion & 0.0 & 0.0 & 3.7 & 2.2 & 0.271 & 2.1 \\
\hline & DNA degradation & 1.4 & 5.6 & 0.4 & 3.8 & 0.271 & 2.6 \\
\hline \multirow{8}{*}{1 AB only } & aneuploid & 55.4 & 70.0 & 72.5 & 82.1 & 0.020 & 72.6 \\
\hline & Monosomy & 33.3 & 12.2 & 28.8 & 13.8 & 0.063 & 21.1 \\
\hline & Trisomy & 0.0 & 12.8 & 18.3 & 16.3 & 0.177 & 13.8 \\
\hline & Multiple & 27.8 & 27.6 & 27.9 & 50.4 & 0.180 & 35.1 \\
\hline & complex & 27.8 & 32.2 & 13.2 & 17.1 & 0.494 & 20.5 \\
\hline & duplication & 5.6 & 8.5 & 6.7 & 2.5 & 0.944 & 5.5 \\
\hline & deletion & 5.6 & 1.5 & 0.8 & 0.0 & 0.558 & 1.4 \\
\hline & DNA degradation & 12.0 & 0.0 & 0.0 & 1.3 & 0.004 & 2.2 \\
\hline
\end{tabular}

blastocyst stage), to the high levels of chromosomal mosaicism at cleavage stages, and also due to the limitation of the genetic testing (FISH) on evaluating the full chromosomal status (Harper, Coonen et al. 2010). By using the $\mathrm{CGH}$, and by performing the biopsy at blastocyst stage, results of several studies indicate that the PGS-CGH may be an effective technique to improve the chances of a normal pregnancy in AMA patients (Treff, 2010; Alfarawati, 2011)

This study found that the rate of aneuploidy in the blastocyst stage embryo undergoes influence of maternal age in most groups evaluated history. However, in the group has only 1 failure in previous IVF cycles the women's age not influence in the risk of embryonic aneuploidy. Secondly, the incidence of aneuploidy was more prevalent in the age group above 40 in most groups. However, the significant increase of aneuploidy in all maternal age groups was present only in the group that has one previous abortion. Although, the analysis of the incidence of different types of aneuplodies or chromosomal errors proved similar in all age groups and study groups.

This suggests that AMA is a more important factor indicator for euploidy, providing only a very rough estimate of the frequency of abnormalities, probably stemming from meiotic recombination defects exacerbated by age (Lamb et al., 1996). Aneuploidy may also be a contributing factor in other infertile populations as recurrent miscarriage couples and repetitive implantation failure. These cases are a challenge to the clinician-because its causes can be multiple and not well defined, and factors from the controlled ovarian hyperstimulation, oocyte and embryo quality as well as from the endometrium or its environment may contribute-among embryonic causes, embryonic aneuploidy has been proposed (SugiuraOgasawara et al., 2012; Margalioth et al., 2006).

The similarity of the results between the groups suggests that a history of infertility is not a predictor for the type of chromosomal error that can be expected from an IVF cycle. This observation can also be evaluated in several studies that evaluated the relationship between ovarian stimulation and aneuploidy, which corroborate the theory that stimulation promotes the recruitment of oocytes with high potential of aneuploidy.

Early research into the effect of FSH on the human oocyte suggested that there was a significant increase in the aneuploidy rate in those oocytes exposed to higher doses of FSH. It has been suggested that exogenous FSH may be associated with increased risk of embryonic aneuploidy. If this association exists, than those patients undergoing controlled ovarian hyperstimulation with exogenous FSH could be at increased risk for miscarriage and trisomic offspring (Nybo et al., 2000; Lathi et al., 2007). Thereby, the indication of the preimplantation genetic diagnosis using comparative genomic hybridization (a-CGH) with 
Table 4b. Analyses of significance differences $(p<0,05)$ between maternal age groups $(A=\leq 34$ years old; $B=35$ to 37 years old; $C=38$ to 40 years old and $D=\geq 40$ years old) and prior infertility history (groups 4,5 and 6 ) according to proposed chromosomal errors. (IVFF $=$ In Vitro Fertilization Failure; $A B=$ abortion)

\begin{tabular}{|c|c|c|c|c|c|c|c|}
\hline & Group & $<=34(\%)$ & $35-37(\%)$ & $38-40(\%)$ & $>40(\%)$ & $\boldsymbol{P}$ & Total (\%) \\
\hline \multirow{8}{*}{$\begin{array}{l}\text { More than } 2 \\
\text { IVFF }\end{array}$} & aneuploid & 61.7 & 58.8 & 71.1 & 88.1 & 0.007 & 70.7 \\
\hline & Monosomy & 22.8 & 20.8 & 12.4 & 5.6 & 0.104 & 14.4 \\
\hline & Trisomy & 16.1 & 20.0 & 20.5 & 13.0 & 0.795 & 18.0 \\
\hline & multiple & 19.3 & 20.8 & 35.1 & 36.1 & 0.133 & 29.6 \\
\hline & complex & 16.8 & 21.9 & 21.3 & 38.2 & 0.104 & 24.7 \\
\hline & duplication & 3.1 & 3.3 & 1.3 & 4.8 & 0.929 & 2.8 \\
\hline & deletion & 11.5 & 9.2 & 5.3 & 2.4 & 0.336 & 6.5 \\
\hline & DNA degradation & 1.3 & 7.3 & 1.7 & 5.7 & 0.136 & 3.7 \\
\hline \multirow{8}{*}{$\begin{array}{l}\text { More than } \\
2 \mathrm{AB}\end{array}$} & aneuploid & 53.1 & 71.1 & 78.4 & 89.7 & $<0.001$ & 75.6 \\
\hline & Monosomy & 31.1 & 22.6 & 28.3 & 23.2 & 0.616 & 25.8 \\
\hline & Trisomy & 21.2 & 3.0 & 29.3 & 8.6 & 0.113 & 21.5 \\
\hline & multiple & 15.2 & 20.2 & 24.3 & 32.0 & 0.380 & 24.1 \\
\hline & complex & 10.0 & 18.5 & 17.2 & 23.6 & 0.387 & 18.3 \\
\hline & duplication & 3.0 & 1.8 & 1.0 & 2.5 & 0.972 & 2.0 \\
\hline & deletion & 11.4 & 6.0 & 0 & 10.1 & 0.432 & 6.8 \\
\hline & DNA degradation & 1.5 & 6.8 & 7.2 & 1.8 & 0.447 & 4.3 \\
\hline \multirow{8}{*}{ No failures } & aneuploid & 53.4 & 59.4 & 73.0 & 83.3 & $<0.001$ & 68.7 \\
\hline & Monosomy & 12.1 & 28.0 & 21.3 & 12.6 & 0.010 & 17.8 \\
\hline & Trisomy & 24.3 & 16.8 & 16.9 & 11.2 & 0.137 & 17.0 \\
\hline & multiple & 19.9 & 15.7 & 27.8 & 29.0 & 0.155 & 24.0 \\
\hline & complex & 25.8 & 21.9 & 23.8 & 42.3 & 0.014 & 29.4 \\
\hline & duplication & 5.2 & 4.3 & 4.5 & 4.0 & 0.891 & 29.4 \\
\hline & deletion & 3.7 & 9.3 & 3.1 & 0.8 & 0.016 & 3.8 \\
\hline & DNA degradation & 0.5 & 9.6 & 2.2 & 6.8 & $<0.001$ & 4.5 \\
\hline
\end{tabular}

24-chromosome screening analysis in embryonic blastocyst stage must always be indicated for couples with abnormal karyotype, recurrent implantation failure, repeated miscarriages and advanced maternal age. However, the pattern of changes that have these groups is similar to patients with no infertility or failure history that are subjected to the process of ovulation induction. Thus, the use of this technology also for couples without previous failure history should be considered as the best tool to define the best embryo to transfer. This procedure could improve the single embryo transfer and reduce the multiple pregnancy rates

\section{CONCLUSION}

The present study demonstrates a slightly increase in the aneuploidies rates in human blastocyst after a-CGH according to the advanced maternal age and with infertility history. However, there was no statistically difference with among chromosomal abnormalities in all groups. Thus, we suggest that the incidence of different types of chromosomal errors based on possible is more correlated with the ovarian stimulation process and not with the couple infertility history. On this evidence, the analysis of embryonic chromosomal complement must always be indicated for couples with a history of previous failures or recurrent miscarriages. However, the pattern of chromosomal error made by these groups is similar to patients with no previous failure in the same age group.

\section{Corresponding author:}

José Roberto Alegretti, Av. República do Líbano, no 529, Ibirapuera, São Paulo, SP, CEP: 04502-001. Fone/Fax: 3059-6100. jalegretti@huntington.com.br

\section{REFERENCES}

Alfarawati,S. E. Fragouli P. Colls and D. Wells. First births after preimplantation genetic diagnosis of structural chromosome abnormalities using comparative genomic hybridization and microarray analysis. Human Reproduction, Vol.26, No.6 pp. 1560-1574, 2011

Armstrong, D. and M. Hutti (1998). "Pregnancy after perinatal Ioss: the relationship between anxiety and prenatal attachment." J Obstet Gynecol Neonatal Nurs 27(2): 183-189.

Armstrong, D. S. (2002). "Emotional distress and prenatal attachment in pregnancy after perinatal loss." J Nurs Scholarsh 34(4): 339-345.

Baird, D. T., J. Collins, J. Egozcue, L. H. Evers, L. Gianaroli, H. Leridon, A. Sunde, A. Templeton, A. Van Steirteghem, J. Cohen, P. G. Crosignani, P. Devroey, K. Diedrich, B. C. Fauser, L. Fraser, A. Glasier, I. Liebaers, G. Mautone, G. Penney and B. Tarlatzis (2005). "Fertility and ageing." Hum Reprod Update 11(3): 261-276.

Bayrampour, H. and M. Heaman (2010). "Advanced maternal age and the risk of cesarean birth: a systematic review." Birth 37(3): 219-226.

Benzies, K., S. Tough, K. Tofflemire, C. Frick, A. Faber and C. Newburn-Cook (2006). "Factors influencing women's decisions about timing of motherhood." J Obstet Gynecol Neonatal Nurs 35(5): 625-633. 
Table 5. Analyses of significance differences between maternal age groups, types of proposed chromosomal errors according infertility history.

\begin{tabular}{|c|c|c|c|c|c|c|c|c|}
\hline Age & Group & $\begin{array}{c}\text { More than } \\
1 \text { IVFF and } \\
1 \text { AB } \\
(\%)\end{array}$ & $\begin{array}{l}1 \text { IVFF } \\
\text { only } \\
(\%)\end{array}$ & $\begin{array}{c}1 \text { AB only } \\
(\%)\end{array}$ & $\begin{array}{l}\text { More than } \\
2 \text { IVFF } \\
\text { (\%) }\end{array}$ & $\begin{array}{l}\text { More than } \\
2 \mathrm{AB} \\
(\%)\end{array}$ & $\begin{array}{c}\text { No } \\
\text { failures } \\
(\%)\end{array}$ & $p$ \\
\hline \multirow[t]{7}{*}{$\leq 34$ years old } & Aneuploidy & 64.2 & 68.1 & 55.4 & 61.7 & 53.1 & 53.4 & 0.701 \\
\hline & Monosomy & 16.7 & 18.8 & 33.3 & 22.8 & 31.1 & 12.1 & 0.143 \\
\hline & Trisomy & 16.7 & 18.8 & 0.0 & 16.1 & 21.2 & 24.3 & 0.333 \\
\hline & Multiple & 35.6 & 46.9 & 27.8 & 19.3 & 15.2 & 19.9 & 0.070 \\
\hline & Complex & 9.2 & 15.6 & 27.8 & 16.8 & 10.0 & 25.8 & 0.603 \\
\hline & Duplication & 0.0 & 0.0 & 5.6 & 3.1 & 3.0 & 5.2 & 0.739 \\
\hline & Deletion & 13.6 & 0.0 & 5.6 & 11.5 & 11.4 & 3.7 & 0.200 \\
\hline \multirow{7}{*}{$\begin{array}{l}35 \text { to } 37 \\
\text { years old }\end{array}$} & Aneuploidy & 63.0 & 63.0 & 70.0 & 58.8 & 71.1 & 59.4 & 0.478 \\
\hline & Monosomy & 32.4 & 27.8 & 12.2 & 20.8 & 22.6 & 28.0 & 0.429 \\
\hline & Trisomy & 12.5 & 15.4 & 12.8 & 20.0 & 31.0 & 16.8 & 0.487 \\
\hline & Multiple & 17.9 & 32.3 & 27.6 & 20.8 & 20.2 & 15.7 & 0.719 \\
\hline & Complex & 22.5 & 24.5 & 32.2 & 21.9 & 18.5 & 21.9 & 0.947 \\
\hline & Duplication & 4.8 & 0.0 & 8.5 & 3.3 & 1.8 & 4.3 & 0.599 \\
\hline & Deletion & 1.0 & 0.0 & 1.5 & 9.2 & 6.0 & 0.0 & 0.220 \\
\hline \multirow{7}{*}{$\begin{array}{l}38 \text { to } 40 \\
\text { years old }\end{array}$} & Aneuploidy & 73.0 & 81.7 & 72.5 & 71.1 & 78.4 & 73.0 & 0.495 \\
\hline & Monosomy & 22.6 & 19.2 & 28.8 & 12.4 & 28.3 & 21.3 & 0.068 \\
\hline & Trisomy & 14.3 & 15.6 & 18.3 & 20.5 & 29.3 & 16.9 & 0.558 \\
\hline & Multiple & 32.4 & 30.4 & 27.9 & 35.1 & 24.3 & 27.8 & 0.776 \\
\hline & Complex & 19.8 & 23.2 & 13.2 & 21.3 & 17.2 & 23.8 & 0.764 \\
\hline & Duplication & 4.6 & 4.3 & 6.7 & 1.3 & 1.0 & 4.5 & 0.684 \\
\hline & Deletion & 3.2 & 3.7 & 0.8 & 5.3 & 0.0 & 3.1 & 0.709 \\
\hline \multirow[t]{7}{*}{$\geq 40$ years old } & Aneuploidy & 85.1 & 80.7 & 82.1 & 88.1 & 89.7 & 83.3 & 0.887 \\
\hline & Monosomy & 14.9 & 13.0 & 13.8 & 5.6 & 23.2 & 12.6 & 0.168 \\
\hline & Trisomy & 7.6 & 6.5 & 16.3 & 13.0 & 8.6 & 11.2 & 0.309 \\
\hline & Multiple & 40.0 & 40.4 & 50.4 & 36.1 & 32.0 & 29.0 & 0.259 \\
\hline & Complex & 35.2 & 31.8 & 17.1 & 38.2 & 23.6 & 42.3 & 0.100 \\
\hline & Duplication & 0.6 & 3.7 & 2.5 & 4.8 & 2.5 & 4.0 & 0.763 \\
\hline & Deletion & 0.0 & 2.2 & 0.0 & 2.4 & 10.1 & 0.8 & 0.041 \\
\hline
\end{tabular}

Carolan, M. and D. Frankowska (2010). "Advanced maternal age and adverse perinatal outcome: A review of the evidence." Midwifery.

Chan, B. C. and T. T. Lao (2008). "Effect of parity and advanced maternal age on obstetric outcome." Int J Gynaecol Obstet 102(3): 237-241.

Couto, E. R., E. Couto, B. Vian, Z. Gregorio, M. L. Nomura, R. Zaccaria and R. Passini, Jr. (2009). "Quality of life, depression and anxiety among pregnant women with previous adverse pregnancy outcomes." Sao Paulo Med J 127(4): 185-189.

Cunniff, C., J. L. Carmack, R. S. Kirby and D. H. Fiser (1995). "Contribution of heritable disorders to mortality in the pediatric intensive care unit." Pediatrics 95(5): 678-681.

de Kretser, D. M. (1997). "Male infertility." Lancet 349(9054): 787-790.

DeBackere, K. J., P. D. Hill and K. L. Kavanaugh (2008). "The parental experience of pregnancy after perinatal loss." ] Obstet Gynecol Neonatal Nurs 37(5): 525-537.

Delhanty, J. D. (2005). "Mechanisms of aneuploidy induction in human oogenesis and early embryogenesis." Cytogenet Genome Res 111(3-4): 237-244.

Dulitzki, M., D. Soriano, E. Schiff, A. Chetrit, S. Mashiach and D. S. Seidman (1998). "Effect of very advanced maternal age on pregnancy outcome and rate of cesarean delivery." Obstet
Gynecol 92(6): 935-939.

Frank, S. A. (2004). "Genetic predisposition to cancer - insights from population genetics." Nat Rev Genet 5(10): 764-772.

Gianaroli, L., M. C. Magli, A. P. Ferraretti and S. Munne (1999). "Preimplantation diagnosis for aneuploidies in patients undergoing in vitro fertilization with a poor prognosis: identification of the categories for which it should be proposed." Fertil Steril 72(5): 837-844.

Gold, K. J., A. Sen and R. A. Hayward (2010). "Marriage and cohabitation outcomes after pregnancy loss." Pediatrics 125(5): e1202-1207.

Goossens, V., G. Harton, C. Moutou, J. Traeger-Synodinos, M. Van Rij and J. C. Harper (2009). "ESHRE PGD Consortium data collection IX: cycles from January to December 2006 with pregnancy follow-up to October 2007." Hum Reprod 24(8): 1786-1810.

Guerneri, S., D. Bettio, G. Simoni, B. Brambati, A. Lanzani and M. Fraccaro (1987). "Prevalence and distribution of chromosome abnormalities in a sample of first trimester internal abortions." Hum Reprod 2(8): 735-739.

Handyside, A. H., E. H. Kontogianni, K. Hardy and R. M. Winston (1990). "Pregnancies from biopsied human preimplantation embryos sexed by Y-specific DNA amplification." Nature 344(6268): 768-770. 
Harper, J., E. Coonen, M. De Rycke, F. Fiorentino, J. Geraedts, V. Goossens, G. Harton, C. Moutou, T. Pehlivan Budak, P. Renwick, S. Sengupta, J. Traeger-Synodinos and K. Vesela (2010). "What next for preimplantation genetic screening (PGS)? A position statement from the ESHRE PGD Consortium Steering Committee." Hum Reprod 25(4): 821-823.

Harris, R. A., A. E. Washington, R. F. Nease, Jr. and M. Kuppermann (2004). "Cost utility of prenatal diagnosis and the risk-based threshold." Lancet 363(9405): 276-282.

Heffner, L. J. (2004). "Advanced maternal age--how old is too old?" N Engl J Med 351(19): 1927-1929.

Hoekelman, R. A. and I. B. Pless (1988). "Decline in mortality among young Americans during the 20th century: prospects for reaching national mortality reduction goals for 1990." Pediatrics 82(4): 582-595.

Hudome, S. M., R. S. Kirby, J. W. Senner and C. Cunniff (1994). "Contribution of genetic disorders to neonatal mortality in a regional intensive care setting." Am J Perinatol 11(2): 100-103.

Hunfeld, J. A., A. Tempels, J. Passchier, F. W. Hazebroek and D. Tibboel (1999). "Brief report: parental burden and grief one year after the birth of a child with a congenital anomaly." ] Pediatr Psychol 24(6): 515-520.

Hutti, M. H., D. S. Armstrong and J. Myers (2011). "Healthcare utilization in the pregnancy following a perinatal loss." MCN Am J Matern Child Nurs 36(2): 104-111.

Inlow, J. K. and L. L. Restifo (2004). "Molecular and comparative genetics of mental retardation." Genetics 166(2): 835-881.

Kanungo, J., A. James, D. McMillan, A. Lodha, D. Faucher, S. K. Lee and P. S. Shah (2011). "Advanced Maternal Age and the Outcomes of Preterm Neonates: A Social Paradox?" Obstet Gynecol 118(4): 872-877.

Lamb NE, Freeman SB, Savage-Austin A, Pettay D, Taft L, Hersey $\mathrm{J}$, et al. Susceptible chiasmate configurations of chromosome 21 predispose to nondisjunction in both maternal meiosis I and meiosis II. Nat Genet 1996; 14:400-5.

Lathi RB, Mark SD, Westphal LM, Milki AA. Cytogenetic testing of anembryonic pregnancies compared

to embryonic missed abortions. J AssistReprod Genet 2007;24:521-4.

Luke, B. and M. B. Brown (2007). "Elevated risks of pregnancy complications and adverse outcomes with increasing maternal age." Hum Reprod 22(5): 1264-1272.

Margalioth EJ, Ben-Chetrit A, Gal M, Eldar-Geva T. Investigation and treatment of repeated implantation failure following IVF-ET. Hum Reprod 2006;21:3036-43.

Mastenbroek, S., P. Scriven, M. Twisk, S. Viville, F. Van der Veen and S. Repping (2008). "What next for preimplantation genetic screening? More randomized controlled trials needed?" Hum Reprod 23(12): 2626-2628.

Menken, J., J. Trussell and U. Larsen (1986). "Age and infertility." Science 233(4771): 1389-1394.

Nybo Andersen, A. M., J. Wohlfahrt, P. Christens, J. Olsen and M. Melbye (2000). "Maternal age and fetal loss: population based register linkage study." BMJ 320(7251): 1708-1712.

Pasupathy, D., A. M. Wood, J. P. Pell, M. Fleming and G. C. Smith (2011). "Advanced maternal age and the risk of perinatal death due to intrapartum anoxia at term." J Epidemiol Community Health 65(3): 241-245.

Pellicer, A., C. Rubio, F. Vidal, Y. Minguez, C. Gimenez, J. Egozcue, J. Remohi and C. Simon (1999). "In vitro fertilization plus preimplantation genetic diagnosis in patients with recurrent miscarriage: an analysis of chromosome abnormalities in human preimplantation embryos." Fertil Steril 71(6): 1033-1039.

Rius, M., G. Daina, A. Obradors, L. Ramos, E. Velilla, S. Fernandez, O. Martinez-Passarell, J. Benet and J. Navarro (2011). "Comprehensive embryo analysis of advanced maternal age-related aneuploidies and mosaicism by short comparative genomic hybridization." Fertil Steril 95(1): 413-416.
Salem Yaniv, S., A. Levy, A. Wiznitzer, G. Holcberg, M. Mazor and E. Sheiner (2011). "A significant linear association exists between advanced maternal age and adverse perinatal outcome." Arch Gynecol Obstet 283(4): 755-759.

Schaeffer, A. J., J. Chung, K. Heretis, A. Wong, D. H. Ledbetter and C. Lese Martin (2004). "Comparative genomic hybridizationarray analysis enhances the detection of aneuploidies and submicroscopic imbalances in spontaneous miscarriages." Am J Hum Genet 74(6): 1168-1174.

Schoolcraft, W. B., M. G. Katz-Jaffe, J. Stevens, M. Rawlins and S. Munne (2009). "Preimplantation aneuploidy testing for infertile patients of advanced maternal age: a randomized prospective trial." Fertil Steril 92(1): 157-162.

Sejourne, N., S. Callahan and H. Chabrol (2011). "[The efficiency of a brief support intervention for anxiety, depression and stress after miscarriage]." J Gynecol Obstet Biol Reprod (Paris) 40(5): 437-443.

Shrim, A., I. Levin, A. Mallozzi, R. Brown, K. Salama, R. Gamzu and B. Almog (2010). "Does very advanced maternal age, with or without egg donation, really increase obstetric risk in a large tertiary center?" J Perinat Med 38(6): 645-650.

Silber, S., T. Escudero, K. Lenahan, I. Abdelhadi, Z. Kilani and S. Munne (2003). "Chromosomal abnormalities in embryos derived from testicular sperm extraction." Fertil Steril 79(1): 30-38.

Skreden, M., H. Skari, U. F. Malt, G. Haugen, A. H. Pripp, A. Faugli and R. Emblem (2010). "Long-term parental psychological distress among parents of children with a malformation--a prospective longitudinal study." Am J Med Genet A 152A(9): 2193-2202.

Sugiura-Ogasawara M, Ozaki Y, Katano K, Suzumori N, Kitaori T, Mizutani E. Abnormal embryonic karyotype is the most frequent cause of re- current miscarriage. Hum Reprod 2012;27:2297303.

Twisk, M., S. Mastenbroek, A. Hoek, M. J. Heineman, F. van der Veen, P. M. Bossuyt, S. Repping and J. C. Korevaar (2008). "No beneficial effect of preimplantation genetic screening in women of advanced maternal age with a high risk for embryonic aneuploidy." Hum Reprod 23(12): 2813-2817.

Treff,N, Brynn Levy, Jing Su, Lesley E. Northrop, Xin Tao, and Richard T. Scott Jr. SNP microarray-based 24 chromosome aneuploidy screening is significantly more consistent than FISH Molecular Human Reproduction, Vol.16, No.8 pp. 583-589, 2010

Vintzileos, A. M., C. V. Ananth, J. C. Smulian, D. L. Day-Salvatore, T. Beazoglou and R. A. Knuppel (2000). "Cost-benefit analysis of prenatal diagnosis for Down syndrome using the British or the American approach." Obstet Gynecol 95(4): 577-583.

Voullaire, L., L. Wilton, J. McBain, T. Callaghan and R. Williamson (2002). "Chromosome abnormalities identified by comparative genomic hybridization in embryos from women with repeated implantation failure." Mol Hum Reprod 8(11): 1035-1041.

Waitzman, N. J., P. S. Romano and R. M. Scheffler (1994). "Estimates of the economic costs of birth defects." Inquiry 31(2): 188-205.

Wang, Y., T. Tanbo, T. Abyholm and T. Henriksen (2011). "The impact of advanced maternal age and parity on obstetric and perinatal outcomes in singleton gestations." Arch Gynecol Obstet 284(1): 31-37.

Yogev, Y., N. Melamed, R. Bardin, K. Tenenbaum-Gavish, G. Ben-Shitrit and A. Ben-Haroush (2010). "Pregnancy outcome at extremely advanced maternal age." Am J Obstet Gynecol 203(6): 558 e551-557. 